\title{
Política em família. Relações de parentesco e facções políticas em um município da Zona da Mata de Minas Gerais.
}

\author{
Luciano Senna Peres Barbosa
}

\begin{abstract}
resumo $\mathrm{O}$ objetivo deste artigo é a análise da maneira como as fronteiras familiares são atualizadas durante as disputas eleitorais em um Município da Zona da Mata de Minas Gerais. Mais precisamente, procuro entender quais os sentidos de se acompanhar o voto do chefe de família, e como as relaçôes de parentesco são empregadas pelos indivíduos para negociar o posicionamento político durante o período eleitoral. Para tanto, na primeira parte do artigo, discuto a maneira como as noçóes de família e parente são manipuladas pelos moradores em seu cotidiano, revelando uma forma específica de conceber o papel das relaçôes de parentesco.
\end{abstract}

palavras-chave Família. Política. Eleições. Facçôes políticas. Zona da Mata de Minas Gerais.

\section{Introduçáo}

O objetivo do presente artigo é analisar como as fronteiras familiares são atualizadas durante as disputas eleitorais. Mais precisamente, procuro entender quais os sentidos de se acompanhar o voto do chefe de família e como as relaçóes de parentesco são empregadas pelos indivíduos em meio à negociação do posicionamento político durante o período eleitoral.

Para tanto, retomo pesquisa iniciada em 2002 em Campos Belos ${ }^{1}$, um município de 15000 habitantes, localizado na Zona da Mata de Minas Gerais. Naquela ocasião, procurei demonstrar como as fronteiras das famílias de políticos eram atualizadas durante o período das eleiçóes municipais. Na presente oportunidade $^{2}$, pretendo ampliar este foco, valendo-me não apenas do período eleitoral, como também da análise do cotidiano das famílias que não estão diretamente implicadas no processo eleitoral (i.e. não são consideradas localmente como uma família de políticos). Neste sentido, meu ponto de partida será uma breve análise dos usos que os moradores fazem dos termos família e parente ${ }^{3}$, tomando como eixo seu emprego nas situaçóes em que há a mobilização de familiares com o objetivo de ajudar um parente necessitado. Na segunda parte do artigo, pretendo associar esta forma de mobilização aos encontros entre familiares durante o período eleitoral, enfatizando seus efeitos sobre a participação dos moradores nas eleições e na forma como as relaçóes de parentesco são concebidas e vivenciadas nesse período.

\section{Emprego, autonomia e família}

Durante a minha primeira estadia em Campos Belos, em 2002, era comum encontrar moradores descrevendo o município através de um discurso que associava o presente à parte culminante de um processo de decadência. Em meio aos diferentes relatos desse processo, algumas situaçóes eram apresentadas como evidências 
do declínio da cidade: a animação perdida dos carnavais de outrora, o desempenho destacado que tiveram os clubes de futebol locais até a década de 1980, e o fim da excitação em torno dos bailes de fins de semana. Esses relatos, dando conta dos aspectos "lúdicos" da vida comunitária, apareciam geralmente acompanhados pela alusão à crise econômica que atingia o município. Esta preocupação intensificar-se-ia quando do surgimento da notícia dando conta da ameaça de fechamento da principal fábrica têxtil da cidade, então a sua maior empregadora individual. A suposta falência da fábrica era encarada como um golpe final na economia municipal, cujos anos de prosperidade, segundo os moradores, encontravam-se num passado distante associado à produção de café.

A percepção sobre o declínio econômico do município era reforçada não somente pelo fato ocorrido em 2002 - que acabou não se concretizando, embora tenham ocorrido demissóes na empresa citada -, mas também pelas dificuldades em se encontrar empregos, evidenciadas pelas filas que se formavam na sede da prefeitura às segundas-feiras, quando eram distribuídas cestas básicas e leite para desempregados assistidos por um programa do referido órgão público. A estes que recorriam à prefeitura interessados nos programas de assistência social, juntavam-se aqueles que procuravam no mesmo prédio (que até recentemente partilhava seu espaço com a Câmara Municipal) algum político ou funcionário próximo a estas figuras, no intuito de obter uma colocação no mercado de trabalho.

Embora recorrentes, as solicitaçóes de inclusão nos programas de assistência financiados pelo executivo municipal, assim como os pedidos de emprego ou outros favores a políticos, eram tidos como atitudes desmoralizantes para o solicitante. Ser visto na "fila da cesta básica" ou adentrar a prefeitura sabendo que ali al- guém reconheceria a sua situação de desempregado eram exemplos correntes utilizados pelos moradores para ilustrar o que era considerado como uma demonstração pública de desprestígio. Situação ainda mais sensível no caso de um chefe de família, de quem se espera ser capaz de prover sua unidade doméstica ${ }^{4}$. Daí a presença majoritária de mulheres nas referidas filas, muitas delas carregando crianças - uma maneira, conforme me afirmara uma das moradoras, de reiterar sua necessidade e, desta forma, a legitimidade de seu pedido.

Se o espaço da prefeitura e os políticos tomados individualmente podem ser considerados como fonte de recursos por parte da população que se mantém distante do vínculo empregatício por longos períodos, quem emprega estes meios corre o risco de se ver desmoralizado, não somente por expor suas dificuldades financeiras, como também porque, ao fazê-lo, evidencia publicamente a ausência de "conhecimentos" que podem ser acionados para contornar esta situação de uma maneira mais bem vista. Em regra, espera-se que alguém recorra inicialmente aos parentes em caso de necessidade. Conforme depoimentos de moradores, entende-se como atitude potencialmente "vergonhosa" para um chefe de família fazer um pedido considerado de maior valor diretamente a alguém que não é seu aparentado. Da mesma maneira, há a expectativa de que um parente reconheça sua obrigação moral de ajudar um aparentado em necessidade, mesmo que esta ajuda venha deixar o solicitante em situação desfavorável. É neste sentido que a ajuda vinda de um parente é concebida como uma maneira legítima de lidar com estas situações de necessidade, garantindo a preservação da reputação dos envolvidos.

No entanto, é importante notar que este dever de assistência a um parente não recai de maneira automática sobre os envolvidos. A 
distribuição de responsabilidades é fluída tal como os limites da família. Assim, torna-se importante entender o que os moradores querem dizer quando utilizam os termos parente e $f a$ mília para definir suas relaçóes de parentesco 5 .

Observei, durante a pesquisa, a existência de uma diferenciaçáo no emprego do termo família quando diz respeito ao parentesco per se - quando, então, os moradores utilizam a terminologia do parentesco que pressupóe, por sua vez, uma série de expectativas baseadas nas relaçóes de gênero e geração (como no uso corrente de fórmulas do tipo: "aonde já se viu um filho falar desta maneira com seu pai?”) - e quando o mesmo termo é empregado em outras ocasiōes cotidianas. No primeiro caso, família refere-se aos consanguíneos e àqueles que formam a família nuclear (pai, mãe e filhos). Ainda conforme esta primeira definição, o termo parente define aqueles com que se têm laços de afinidade - daí a divisão recorrente em enunciados como: "Ele é meu parente, mas não é da minha família. Não tem meu sangue"; "Ele era da família, era o tio verdadeiro dele, o outro era tio falso [afim]”. O termo parente também é usado para se referir a consanguíneos e afins de maneira genérica (como na expressão: "aqui é tudo parente”). Já em seu emprego em outras ocasiôes cotidianas, o termo família refere-se a consanguíneos e afins com quem se mantém proximidade social. Neste caso, o termo parente é empregado para se referir a um familiar em potencial, a quem falta esta proximidade social que define a condição de família.

Sendo assim, o dever moral de ajudar um parente é mais bem descrito como a obrigação de assistência a alguém da família, ou seja, a um familiar/parente socialmente próximo. Contudo, essa distinção pode ser enganosa se tomada como uma diferença objetiva. É necessário levar em conta que a proximidade social é atualizada constantemente e que prestar aju- da é um dos meios capazes de transformar um parente em família. Ou seja, a distinção entre família e parente é operacional e não uma diferença estabelecida de uma vez por todas.

Essa dinâmica é mais bem observada nos casos em que o pedido do suposto familiar é considerado como de difícil acesso ou excepcional - o que vai variar conforme a condição econômica dos envolvidos ${ }^{6}-$, tal como nas situaçóes envolvendo a prestação de serviços médicos, no cuidado permanente a crianças e idosos, em empréstimos para cobrir dívidas financeiras ou na obtenção de postos de trabalho. Nestes casos, o recorte das fronteiras da família tende a se ampliar, ou seja, espera-se que alguém nessa situação procure a ajuda de um parente tal como se este fosse um familiar.

$\mathrm{O}$ aspecto circunstancial desta definição de família (o que talvez tornasse mais exato perguntar "quando" alguém é da sua família) não implica na inexistência de um eixo a partir do qual a expectativa de solidariedade mútua entre familiares é orientada. Em regra, cabe ao chefe de família definir quando e quem deve ser procurado em caso de necessidade, assim como a decisão de quem deve ser retribuído e quais favores podem ser prestados para que parentes ou familiares.

Essa autoridade do chefe de família tende a diminuir quando se torna necessário mobilizar um conjunto maior de pessoas. Conforme já assinalei, não se espera que o chefe de família requeira auxílio de alguém com quem não mantém uma relação socialmente próxima, o que inclui parentes. Nestes casos, entra em ação o papel de mediação desempenhado usualmente pelas mulheres- a mãe, as irmãs e as cunhadas. Cabe a elas alertar outros parentes sobre a necessidade do familiar, além de fazer circular informaçóes entre seus respectivos maridos e outros parentes sobre o posicionamento dos envolvidos e das opinióes sobre seus respectivos 
posicionamentos, dando forma a um conjunto de negociações em torno da distribuição de responsabilidades entre possíveis familiares.

Ressalva-se que raramente estas negociações são formalizadas. A mobilização de parentes desenvolve-se em meio a encontros cotidianos, durante visitas a casa de familiares, telefonemas, ou mesmo em festas (comemorações de aniversário, casamento, batismo, etc. $)^{7}$. Além disso, o andamento dos pedidos aos parentes ocorre, na maioria dos casos, sem uma coordenação reconhecida pelos envolvidos e sem o conhecimento por parte do chefe de família que é o alvo da ajuda - mesmo quando a ajuda não se refira a ele pessoalmente, mas a alguém de sua família sob a sua autoridade. De fato, seria mais exato afirmar que a existência de uma coordenação da cooperação entre parentes e o conhecimento do chefe de família são dissimulados ao longo do processo. Em ambos os casos, pretende-se resguardar a reputação do chefe de família ao não admitir qualquer interposição de uma autoridade sobre a sua figura de provedor da unidade doméstica. Tanto que o desfecho considerado ideal nestes casos é aquele envolvendo a ajuda "imprevista" de um ou vários parentes tidos como "distantes" na perspectiva do chefe de família.

De todo modo, embora seja tratada como um segredo e um assunto "delicado", a mobilização de parentes acaba se tornando pública, resultado da atuação daqueles a quem cabe o trabalho de mediação. Espera-se que as mulheres envolvidas neste papel respeitem toda uma etiqueta que privilegia a cautela e a discrição, que se consubstancia na valorização da habilidade com que se escolhe a quem dirigir o pedido e a maneira como este é realizado. Neste último caso, está em jogo saber quando cobrar a ajuda, empregando uma espécie de exposição das causas que levaram à situação de necessidade do aparentado e da relação entre este e a quem se está dirigindo. Toda a cautela e a aparente preocupação com o controle sobre a publicidade da condiçấo do familiar necessitado concorrem, por outro lado, para o estabelecimento de uma dinâmica que resulta na expansão do número de envolvidos no caso. Tal expansão deve-se ao menos a dois fatores: primeiro, a necessidade de angariar recursos para concretizar a prestação da ajuda motiva a procura do maior número possível de parentes; segundo, durante essas negociaçóes, os envolvidos procuram seus respectivos familiares para justificarem suas decisôes - mas, como estes familiares não são necessariamente comuns, tem-se uma contínua difusão do acontecimento ${ }^{8}$.

A cautela quanto à elaboração do pedido, assim como o controle sobre a publicidade do caso, também podem ser vistos como precauçôes em meio a uma espécie de teste dos limites das lealdades familiares. Se, na perspectiva do chefe de família, receber auxílio de familiares não afeta sua reputação, durante as negociaçóes que podem levar à composição da ajuda, nem sempre há certeza de como reagirá o parente requisitado. Pedir auxílio a uma pessoa errada ou de maneira incorreta - isto é, ter o pedido negado publicamente e/ou de maneira tida como ofensiva - pode não apenas expor o alvo da ajuda, como ainda gerar conflitos no interior da família, colocando em risco a reputação de todos os envolvidos.

Para tentar escapar desses riscos, era comum a manipulação das relaçóes de parentesco a fim de enquadrar o pedido em sua forma legítima. Revela-se, então, o caráter operatório tanto da terminologia do parentesco tomada per se quanto da reconstrução do histórico de relaçôes entre familiares. Assim, ora se reafirma a condição de família enfatizando-se a proximidade social - é este o sentido do diálogo entre duas moradoras (mãe e filha) sobre as dificuldades financeiras de um primo, em 
que a mãe cobra a ajuda da filha: "Você tem que lembrar que Laerte, além de ser seu primo, me ajudou muito quando eu estava grávida” ora se desconsidera esta condição em termos genealógicos - um exemplo do emprego deste argumento pode ser visto no caso envolvendo um morador que, ao justificar o fato de não ter votado em seu cunhado, entáo candidato a vereança, lembrava que: "Raul é meu cunhado, é meu parente, mas não é do meu sangue”.

Seria enganoso tratar esta mobilização de parentes nos momentos de necessidade extracotidiana como evento cujos únicos resultados possíveis são a aproximação de familiares ou seu rompimento. Entre aceitar um pedido e negá-lo há um espaço composto por atenuantes, compensaçôes e tolerância. Os atos que compóem este espaço - ajuda de menor valor do que o pedido ou esperado, a postergação do auxílio ou da retribuição, ou sua divisão em parcelas a serem "pagas" ao longo do tempo - são acompanhados por práticas discursivas que, juntos, definem uma série de estratégias a partir das quais cada indivíduo busca ora se ausentar da responsabilidade, ora dividi-la com outros, ora condicionar sua recusa a garantias de benefícios futuros, ora fazer com que retribuiçôes no presente recuperem faltas anteriores - em suma, definir a sua posição e, com isto, suas atribuiçôes familiares sem necessariamente atender ao pedido ou negá-lo, ou, finalmente, sem que haja uma ruptura nas relaçóes cotidianas.

Sendo assim, as negociações em torno da distribuição de responsabilidade em assistir um parente, que acionam a retórica dos laços de parentesco e o histórico de relaçóes entre aparentados, também podem tomar a forma de uma espécie de "balanço". Nesta operação, são contabilizados os custos de ajudas passadas e das retribuições recebidas, ou prometidos favores futuros (em forma de serviços ou dinhei- ro) tendo em vista a proximidade social com o possível contemplado e os membros de sua família. Por exemplo, um morador (funcionário público casado e pai de dois filhos) relatava-me como não entendia as reclamaçôes diárias de sua irmã e vizinha, então recém-separada, sobre problemas financeiros já que: "ela recebe salário 9 e o filho dela sempre almoça e janta aqui todo dia"; concluindo: "entâo, você vê, ela não tem custo com mercado, só com roupa $\mathrm{e}$ estas coisas mais. Então, eu não tenho que ouvir esta conversa todo dia. Eu não sou o marido dela, não posso ajudar mais”.

Seja qual for a justificativa empregada nestas negociaçóes, o fato é que raramente estas levam a uma resolução definitiva. As discussóes em torno da responsabilidade de aparentados entre si são momentos específicos da constante redefinição de fronteiras familiares, mantidas pela tensão entre a obrigação moral de ajudar um familiar em dificuldades - sem colocar em risco a união da família e, consequentemente, a reputação dos envolvidos - e a necessidade do chefe de família manter sua autonomia, não aceitando ajuda de qualquer parente.

\section{A política}

Não obstante a tentativa de limitar ao interior da família os pedidos de ajuda em caso de necessidade extraordinária, os recursos a não parentes são frequentes. Como viemos argumentando até aqui, esta situação opóe-se à imagem valorizada do chefe de família enquanto provedor e gestor das relações públicas da unidade doméstica - ou, como nos termos dos moradores, corre-se o risco de ser avaliado como um encabrestado, alguém que depende dos outros. Contudo, há formas de legitimar o pedido a não parentes sem que se coloque em 
I24 | Luciano Senna Peres Barbosa

risco a reputação do requerente. Como assinala Comerford (2003), em contexto semelhante ao que analiso aqui, a ajuda recebida pode ser interpretada como um sinal do reconhecimento do valor e da dignidade do receptor e como expressão do prestígio social do doador. Para tanto, ainda conforme Comerford (2003, p. 121), faz-se necessário que ambos realizem um trabalho conjunto de imposição da definição pública da situação, ressaltando o caráter justificável da ajuda.

Conversas travadas com moradores permitem-nos afirmar que este trabalho conjunto em favor da imposição de uma interpretação favorável da ajuda é usualmente descrito pelo receptor como parte de uma relaçáo personalizada que este mantém com o doador. Relação pensada também em termos de uma dívida moral que, por ser de difícil retribuição, tende a gerar uma série de contraprestaçóes ao longo do tempo que reafirmam o reconhecimento da ajuda prestada em forma de gratidão (Palmeira, 1996, p. 63). Assim, não nos parece mera coincidência o fato de que a definição destas trocas empregue um vocabulário em alusão às relações familiares, tal como ocorre nos âmbitos da amizade, da vizinhança e do compadrio. Daí as afirmaçóes recorrentes do tipo: "Luís me trata como um irmão"; "Seu Valdir foi um pai que eu não tive, me ajudou muito quando comecei a trabalhar".

A importância de representar publicamente o reconhecimento da ajuda recebida ou os laços de amizades com o doador - em suma, de dotar tal relação com uma face voluntária e, assim, legítima - exige que o chefe de família busque ocasióes para reafirmar tal definição. $\mathrm{O}$ período que os moradores denominam como "tempo da política" (Palmeira e Heredia, 2010, p. 168) - associado frequentemente às eleiçóes municipais - é uma das principais oportunidades para esta ratificação. $\mathrm{O}$ apoio público antecipado a um candidato ou a uma candi- datura apoiada por alguém com quem se sente compromissado permite ao chefe de família enquadrar sua dívida com seu suposto credor enquanto parte de uma relação legítima. Neste caso, a política é interpretada como um espaço de relações solidárias - a identificação comum a uma facçáo ${ }^{10}$ - onde o pedido, a ajuda e a retribuição através do voto podem ser redefinidos em termos de uma troca de favores entre parceiros em mútua cooperação. Assim, mesmo nos casos em que a dívida não é reconhecida pelo suposto credor, é possível observar moradores tomando seu voto como meio de retribuição que atualiza uma suposta relação de amizade ou de compromisso - a qual, por sua vez, reafirma seu papel enquanto chefe de família respeitável, ou seja, como alguém exercendo o dever moral de retribuiçáo de forma voluntária. Em ambos os casos, trata-se de tentar distanciar-se de qualquer insinuação de dependência, de cabresto.

Todavia, não basta que o chefe de família demonstre seu apoio a uma candidatura publicamente para qualificar o recebimento de ajuda “externa”. Para tanto, é necessário também que sua familia o acompanhe. Contar com o apoio da família ou votar junto com a família é visto, em regra, como prova da legitimidade do voto. Mais especificamente, qualifica o voto como demonstração de lealdade a um candidato ou a um partido. Inversamente, votar em desacordo com a posição da família ou não contar com seu apoio pode ser caracterizado como prova do $c a-$ bresto, ou seja, da relação de dependência para com o candidato ou um de seus correligionários. Observemos, neste sentido, a justificativa acionada por um funcionário público, candidato derrotado a vereador, para explicar sua troca de partido: "Eu mudei de lado, mas eu estava certo. Tanto que a minha família toda veio junta".

O "problema", na perspectiva do chefe de família e daqueles ligados à sua pessoa, é 
a ausência de um critério capaz de definir sobre quais membros da família deve recair tal obrigação de acompanhar o voto, dada a indefinição, ou melhor, a constante redefinição das fronteiras familiares no cotidiano. É neste ponto que surgem os inúmeros casos de discordância entre as expectativas familiares e políticas, que tornam o "tempo da política" um momento em que se coloca em jogo a reputação não só do chefe de família, mas da família como um todo.

A possibilidade do posicionamento de um familiar causar embaraço para o restante da $f a$ mília (ou seja, o fato de que o posicionamento de um suposto familiar tende a se refletir na forma como é avaliado o posicionamento do restante da família) acaba estabelecendo uma diferença na acepção deste termo no tempo da política quando comparado a outras ocasióes em que está em jogo a obrigação de ajudar um parente. Assinalei anteriormente como a existência de meios para lidar com a instabilidade das lealdades familiares durante o processo de ajuda a um parente impedia a reificação da família. No entanto, a disputa eleitoral impóe uma lógica distinta, onde tertium non datur, ou seja, não "acompanhar" o voto da família, não implica somente na ameaça de um rompimento de relaçóes familiares: trata-se de se colocar contra estas figuras publicamente, pondo em risco a reputaçáo de todos. Daí o maior controle mútuo entre familiares durante o tempo da política - o que, finalmente, resulta no enrijecimento das fronteiras da família. Ou seja, enquanto no cotidiano dos moradores da cidade pode-se pertencer simultaneamente a diferentes famílias, durante o tempo da política essa indistinção só se torna possível entre familiares que apoiam um mesmo lado ou os mesmos candidatos.

Este enrijecimento das fronteiras familiares, que surge como consequência da tentativa de adequar a necessidade de retribuição de um favor "externo" à expectativa familiar, é também decorrência da simultaneidade com que esse dilema atinge praticamente todas as familias.

Esta última observação deve ser entendida levando em conta que a disputa eleitoral municipal não atinge a todos moradores, nem o faz da mesma maneira. Ainda assim, seria infrutífero buscar um critério objetivo para delimitar o "grau" ou a "forma" de participação, uma vez que ela é parte do próprio objeto em disputa. Como viemos argumentando, na perspectiva do "eleitor", tão importante quanto retribuir um favor por meio do voto é demonstrar sua autonomia em relação à política. Só porque se é reconhecido como autônomo que a retribuição através do voto pode ser definida enquanto parte de uma relação legítima. Autonomia aqui não significa alheamento, mas um posicionamento não motivado por interesses particulares ou pela imposição de não familiares. Na prática, este alheamento nunca é possível, dada, entre outros motivos, a fluidez da composição familiar. De maneira que toda afirmaçáo de alheamento em relação à política é, em regra, desmentida ao se apontar um familiar do suposto "autônomo" beneficiado por alguma figura ligada à política local, o que torna a dívida contraída extensiva à sua pessoa. Talvez aí se encontre um dos fatores - junto ao fato de que o apoio familiar opera como sinal de desinteresse - que fazem com que a família sempre esteja presente nas discussóes políticas no período. Neste sentido, tudo leva a crer que, se a fluidez das fronteiras familiares opera como uma força de atração em direção à disputa política, o enrijecimento destas mesmas fronteiras aparece como um modo de limitar a extensão desta disputa para o interior da família.

Talvez o melhor exemplo de como esta reificação da representação da família opera durante o tempo da política esteja no emprego 
do que os moradores denominam de "tradição familiar na política”. Em geral, esta expressão sugere a identificação construída ao longo do tempo entre a familia e uma facção. No entanto, é interessante notar como tal associação é mantida mesmo quando um morador reconhece que ele e seus familiares já votaram no outro lado - como, por exemplo, na justificativa de um candidato a vereador para suas viradas: "Naquela política eu tive de acompanhar o PFL, mas eu acabei voltando. Sabe como é, minha família sempre foi PMDB”. Se esta observação já relativiza a inflexibilidade geralmente atribuída pelos moradores à tradição política de sua família, bastaria colocar a questão sobre a composição desta familia para se revelar como a identificação a uma facção pressupóe um recorte operatório e, desse modo, circunstancial.

Pesquisador: Mas quando você diz que toda a sua família sempre foi PMDB, a quem você se refere?

Entrevistado: Todo mundo. Sabe como é: meu pai, meus irmãos, meus tios, meus primos. Tem aqueles que são do outro lado... é gente mais afastada. Tem também um irmão meu que tá agora no PFL. Mas a gente se dá muito bem. Só na política que agente acaba se falando pouco. Política tem estas bobeiras.

Com efeito, a "tradição familiar na política" é mais bem entendida quando concebida como uma justificativa do voto. É comum encontrar aqueles que explicam a decisão de seu voto em uma facção remetendo a uma "tradição passada de pai para filho", descrita também como uma tendência de caráter hereditário, transmitida pelo sangue: "Eu sou PMDB, está no sangue, não tem jeito". Mais uma vez, trata-se da tentativa dos moradores de ressaltarem como o po- sicionamento em relação ao embate faccional não se deve a um interesse individual, a uma relação de dependência para com um candidato ou mesmo a um favor recebido por um não parente - mas, neste caso, como o cumprimento de um dever perante a família.

A demonstração de desinteresse através da alusão à tradição política familiar leva a associá-la a uma concepção de política em que a disputa entre os lados é descrita como uma competição lúdica. Assim, mesmo que eventualmente se defina sua origem a partir um dado favor recebido por um ascendente no passado - ou em outros casos, por um conflito anterior envolvendo um familiar -, a origem $\mathrm{da}$ tradição familiar na política também pode ser associada a outras formas de competição, como as que dividem os torcedores dos times de futebol do município e dos clubes carnavalescos, em que a vitória no pleito motiva o lançamento de provocaçóes ao adversário batido. Isso fica claro na fala de uma professora local quando questionada sobre as razóes da tradição política de sua família: "Esta coisa vem de antigamente, lá do tempo dos Borges. Eu nem sei te explicar direito porque meu avô ficou do lado dos Borges. Essa coisa é que nem era no futebol: o Januário e o Esporte, você era um e ficava contra o outro. Era que nem no carnaval, uns era Rosa e Branco, e outros era Verde e Branco. Vai saber o porquê".

Se o "tempo da política" aparece como um desafio externo que coloca em questão a reputação da família - tanto no que se refere ao reconhecimento da sua autonomia (não ser encabestrado, "depender de política" ou "dever favor a ninguém”) quanto em relação às potenciais humilhações de uma competição lúdica -, ele também é entendido como um desafio interno, no momento em que familiares concorrem entre si por recursos que, uma vez obtidos, impóem uma diferenciação entre as partes. Foi 
Beatriz Heredia (1996) quem chamou a atenção para os conflitos que surgem quando se tenta, através da política, impor uma relação de desigualdade em unidades que valorizam a igualdade (a família, a comunidade). Daí um dos motivos da resistência de familiares em apoiar a candidatura de um membro da familia, ou dos casos quando familiares rompidos valem-se da politica como um meio de dar continuidade a suas disputas - como no exemplo observado em que uma disputa por herança apareceu como uma das razóes para que dois irmãos concorressem a um cargo a vereança.

Note-se que, neste último caso, a política é pensada como um período de oportunidades de acesso - ou, ao menos, de facilitação - à obtenção de bens tangíveis ou intangíveis por meio da intermediação de políticos. Não é difícil presenciar conversas em que moradores definem suas estratégias para a aquisição de um recurso levando em conta o calendário político. Um exemplo vem do mesmo funcionário público já citado, que afirmou ter "esperado mais de um ano" para reclamar dos defeitos no calçamento de sua rua, pois sabia que só seria escutado durante a política. No mesmo sentido, uma moradora lembrava a ocasião quando se valeu da visita em sua casa de um oftalmologista que concorria à vereança para conseguir uma consulta gratuita e um desconto na compra de óculos numa loja em outro município. Talvez por não conhecer o oftalmologista, a moradora decidiu usufruir do desconto sem retribuí-lo com seu voto, pois, para ela, "Tem que se aproveitar dos políticos enquanto pode, porque depois eles se aproveitam da gente".

É importante deixar claro que tais concepções não resumem as razôes acionadas pelos moradores para explicarem a decisão do voto. De fato, seria difícil, e mesmo infrutífera, a realização de um levantamento sistemático destas razóes, uma vez que estas só ganham sentido em referência a uma relação social concreta. Ou seja, não nos parece possível isolar estas concepções aferindo, a partir delas, supostos valores que explicariam o comportamento político dos moradores. Sendo assim, para entendermos a dinâmica entre as relaçóes familiares e a politica - mais exatamente, a maneira como os moradores lidam com as possíveis discordâncias entre as expectativas familiares e políticas -, é necessário analisar as concepçóes de voto e sua relação com o pertencimento familiar que apresentei até aqui em seu significado prático, ou seja, a partir da maneira como são empregados em uma situação concreta. É com este intuito que passarei à próxima parte do artigo.

\section{A política e a família}

Durante o "tempo da política”, os comentários sobre a disputa eleitoral tornam-se onipresentes no cotidiano dos moradores. Possíveis trairagens $^{11}$, ataques verbais entre os candidatos, acordos envolvendo trocas de bens por votos, estimativas da força das candidaturas e as promessas são temas constantes nas avaliações das açóes daqueles que vão se tornando protagonistas da disputa eleitoral. É também a partir destas avaliaçóes do que se passa na campanha e da percepção de como suas próprias ações são vistas em meio aos acontecimentos que os moradores procuram definir suas açóes futuras. Ou seja, é por meio dessas conversas que os interlocutores buscam se situar em meio à campanha eleitoral.

Mas, se por esta razão, "todo mundo só fala de política”, é fato que não se conversa sobre este assunto com qualquer um, em qualquer lugar e de qualquer maneira. Abordar um contrário para se falar de política durante o "tempo da política” pode ser visto como uma provoca- 
ção ou mesmo um insulto. Se, por outro lado, a conversa sobre política com partidários não apenas é aceita, como geralmente desejada - é comum a procura por pessoas que "sabem de tudo o que está acontecendo" -, tal abordagem não deixa de exigir algumas precauçôes dependendo do interlocutor e do contexto, uma vez que partidários podem ser concorrentes de bens acessíveis à facção caso esta seja vitoriosa ${ }^{12}$. Os próprios moradores costumam opor a liberdade para expressar suas opinióes sobre os acontecimentos da campanha nas conversas entre familiares e a interdição do assunto quando se está na presença de um contrário. Entre estes polos, encontram-se as reunióes informais com amigos em bares e festas - quando o tema surge espontaneamente - e reunióes políticas formais com a participação de candidatos, cujo objetivo declarado é definir estratégias de campanha. Em ambos os casos, os participantes procuram estabelecer suas posições através da avaliação das tomadas de posiçóes de outros, mas raramente se discutem as posiçóes tomadas individualmente, dado o receio de que suas palavras possam ser interpretadas como provocaçóes.

Se, na comparação realizada pelos moradores, as conversas entre familiares - que nos interessam aqui - têm por especificidade a maior liberdade para comentar os eventos políticos, não significa que nestas ocasióes estejam suspensos os interesses cotidianos e a hierarquia. A percepção de liberdade está ligada à existência de um comprometimento mútuo quanto à preservação da reputação familiar. Esperase que familiares na politica não busquem se desqualificar em público, o que parece explicar a menor observância quanto à precaução exigida quando se refere à disputa eleitoral em família. Esta mesma percepção de que a reputação de um membro reflete-se na reputação do restante da família revela a outra face da referida liberdade, qual seja, o maior consenti- mento em relação às críticas dirigidas aos interlocutores. Em regra, as conversas sobre politica entre familiares são pontuadas por acusaçóes, repreensóes e ordens dirigidas aos participantes. Assim, se por um lado a liberdade se expressa no "falar sem preocupaçáo" - enquanto uma sinalização de que se confia no interlocutor -, por outro, define uma ocasião para o exercício do controle da expressão pública da família durante a campanha eleitoral.

Contudo, tal como ocorre nas negociaçóes de ajuda a um parente, a fragmentaçáo destas conversas torna difícil a apreensão da maneira como se dá este controle. Observando o fluxo de conversas entre familiares, foi possível delimitar uma ocasiáo em que estas diferentes falas parecem se agregar em um único momento - o que defini como reuniāo familiar. É importante deixar claro que estas reuniōes familiares não são organizadas com o propósito de discutir política, tratando-se antes da inserção deste assunto em encontros cotidianos. Neste mesmo sentido, também é preciso lembrar que há certa fluidez na distinção entre um encontro casual e uma reuniáo familiar quanto ao número de participantes, sendo a distinção entre estes dois eventos definida aqui pela presença de membros de mais de uma unidade doméstica que compóem uma mesma família. Assim, defini a reunião familiar, enquanto categoria analítica, como uma parcela arbitrariamente recortada de um fluxo de conversas que ocorre em espaços reservados, envolvendo membros de diferentes unidades domésticas que se consideram de uma mesma família em um dado momento.

O tom circunstancial e pouco formalizado destas reunióes pode ser averiguado ao olharmos para a sua dinâmica conversacional. Durante estas ocasióes, é comum que todos falem ao mesmo tempo e que conversas paralelas concorram entre si para monopolizar o centro das atençóes (de fato, gerando este centro). Para tanto, valem-se do seu conteúdo, do en- 
volvimento de mais pessoas ou mesmo do tom com que as frases são proferidas. Outra variável importante nestes encontros é a autoridade daquele que busca ser escutado e, mais do que isso, determinar qual assunto será debatido. Em geral, é atribuição do chefe de família repreender outros participantes (no caso, repreender os membros de sua unidade doméstica) quando quer estabelecer a ordem das falas.

Embora geralmente haja espaço para o exercício desta forma de autoridade, não está em jogo nestas reunióes uma disputa sobre o controle de uma suposta liderança que viria a definir a expressão pública do posicionamento político familiar. Trata-se, antes, de uma dinâmica em que os envolvidos, ao buscarem afirmar sua posição no interior da família, acabam definindo a maneira como esta se colocará frente ao público em meio à disputa eleitoral. Mais do que uma estratégia comum a ser seguida, tem-se uma expressão sempre variável, decorrente dos efeitos que se seguem às conversas e debates entre familiares.

Para entender melhor como a dinâmica destas reunióes define o posicionamento familiar na politica (ao mesmo tempo em que atualizam as fronteiras familiares), faz-se necessário acompanhar seu desenvolvimento durante o andamento da campanha eleitoral. Sendo assim, limitar-nos-emos à análise de um caso específico com o objetivo de acompanhar como estes encontros desenvolvem-se durante uma campanha eleitoral.

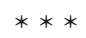

Todas as reunióes a que me refiro, a partir deste ponto, ocorreram na residência de Alfredo, funcionário público aposentado, viúvo, que morava com sua filha mais nova, Rita, solteira, funcionária da prefeitura. Ocupando a laje desta casa e o restante do terreno, encontravam-se mais três residências onde moravam seus filhos José, João e Cláudia - os dois primeiros casados e a última, divorciada, cada qual com um filho. Antônia, outra filha, também casada, sem filhos, morava em outro bairro na sede do município. Além de contarem com a presença da maioria de seus filhos, genros, noras e netos, as reuniōes na casa de Alfredo também incluíam, ocasionalmente, outros familiares, parentes ou amigos.

Alfredo e sua família eram identificados como eleitores do PMDB - razão que teria garantido um cargo na prefeitura à sua filha solteira. Ainda assim, não eram tidos como cabos eleitorais ou partidários - no sentido de pessoas que trabalham para determinados políticos locais durante uma campanha -, tendo limitado suas participaçóes durante as eleiçóes à presença em manifestaçóes públicas do partido - com exceção de certa ocasião, quando uma das filhas de Alfredo tornou-se protagonista de uma disputa gerada após a vitória do PMDB em um pleito municipal (evento sobre o qual falaremos mais adiante).

A minha inserção neste espaço deu-se durante trabalho de campo realizado em 2002 através de contatos locais que me sugeriram um encontro com Alfredo, conhecido localmente como um pesquisador da história da cidade. Contando com a colaboração sempre simpática do "informante", voltei a entrar em contato, frequentando sua casa ocasionalmente durante um período de três meses (de agosto a outubro) em 2004 - ou seja, em meio à campanha municipal -, tendo realizado, na soma dos dois períodos, cinco entrevistas gravadas, além das conversas casuais durante fins de semana - quando pude, então, observar boa parte das reuniōes familiares. 
I30 | Luciano Senna Peres Barbosa

A primeira reunião na casa de Alfredo em que estive presente ocorreu em agosto de 2004. Talvez pela repercussão das convençóes partidárias, então recém-concluídas, o debate em torno da "força" dos possíveis candidatos ${ }^{13}$ fora o tema preponderante.

Levantado o assunto, estabeleceu-se uma espécie de competição entre os presentes em torno da previsão dos resultados eleitorais. Cada um procurava apresentar novos fatos capazes de demonstrar a validade de suas apostas. Com o mesmo intuito, buscava-se valorizar suas fontes - o que, consequentemente, terminava por revelar o conjunto de relaçóes externas à familia que cada membro possuía.

Esta demarcação de uma esfera de individualidade com relação à família detém um significado específico para aqueles considerados jovens. Estes dependem economicamente de seus pais, mas já procuram ascender a uma posição de maior autonomia. Para estes, a demonstração do conhecimento de informaçóes derivadas de fontes exteriores ou desconhecidas da família (que podem até mesmo apregoar compromissos obtidos com não parentes) torna-se um importante meio de manifestação de sua condição pretendida ${ }^{14}$. Assim, durante o referido encontro, Carlos, filho de José (estudante que morava com seu pai), contou haver escutado o relato de um candidato a vereador sobre a troca de facção de um político do PMDB. A informação, reconhecida como uma novidade pelos presentes na ocasiáo (Alfredo, Rita, Antônia, José, João e sua esposa) - não apenas pelo fato relatado, mas também pela revelaçáo do contato do familiar com o político - garantiu ao filho de José a atenção dos presentes, que passaram a lhe colocar uma série de questóes, como que tentando comprovar a veracidade do relato. E seria também um comentário de Carlos após uma pergunta de seu avô que evidenciaria como não bastava trazer informações novas, era necessário saber como proferi-las - no sentido restrito de associar a informação dada a comentários válidos. Ao responder uma questáo sobre onde teria ocorrido uma suposta reuniáo entre o traíra e as lideranças do PSDB, Carlos faz uma associação do local (um sítio localizado em um distrito rural) e a suposta força política do traíra junto à população da "roça”. Em suas palavras: "ele é muito forte na roça, e quem é forte na roça ganha política”. É este comentário que o faz perder o centro da conversa, atravessada a partir daí por uma série de desmentidos à sua avaliação. Foi sentenciado, finalmente, por seu pai, que se vale desta "falha" para reafirmar sua autoridade: "Você é muito menino, não sabe como é política".

Além da atualização de papéis familiares, durante as reuniôes é possível observar uma constante avaliação dos limites da família - tal como evidenciado durante as negociaçóes em torno da distribuição de responsabilidade de ajuda a um parente. Mais precisamente, trata-se dos bate-bocas que pontuam estas ocasióes, espécie de conflito encenado que se diferencia das brigas, pois não leva ao rompimento das relaçôes entre familiares, embora revele, ao mesmo tempo, como esta possibilidade está sempre presente. Tudo leva a crer que, nestes bate-bocas, ao se demarcar uma posição, está-se também buscando o reconhecimento de seu valor (e, assim, seu pertencimento) à família.

Os bate-bocas têm origens diversas, sendo comuns, durante o "tempo da política", os que se referiam às divergências quanto a como e a quem se deve apoiar na facção identificada à família. Voltemos à ocasião que nos serviu de exemplo no parágrafo acima. A discussão acerca da influência do "voto da roça" leva, em seguida, aos comentários sobre as políticas passadas, enfatizando a participação familiar nestas ocasióes. $\mathrm{O}$ assunto aos poucos vai associando 
o histórico das disputas eleitorais à trajetória de membros da família através de lembranças partilhadas sobre a participação em comícios, brigas em rua (nas quais os presentes não teriam tomado parte, apenas presenciado) e as grandes vitórias e derrotas (as "viradas") nos pleitos. Lembranças essas seguidas de um comentário de José dirigido ao pesquisador: "mas isso é coisa do passado, e essa coisa de partido já acabou”. A aparente intenção em demonstrar seu distanciamento em relação à política é reforçada pelas consideraçóes de José acerca da narrativa de seu pai (Alfredo) sobre a campanha em que o então "MDB" teria vencido o "PDS” pela primeira vez, ainda nos anos 1970. Nesta ocasião, um amigo de infância de Alfredo, Jaime, foi eleito prefeito. José aproveita a menção de seu pai para descrever como Jaime, então eleito, teria passado a desviar verbas para a compra de propriedades rurais e se aproveitado de contratos da prefeitura para beneficiar suas atividades empresariais. Alguns dos presentes procuram, em seguida, contemporizar - iniciando o bate-boca -, afirmando que tais acusaçóes nunca haviam sido provadas ou que José não o conhecia tão bem, ou lembrando, ainda, que o importante em política é saber o que "o político faz pra mim". Questionado pelo pesquisador sobre a razão de continuar votando em Jaime, uma vez que ele era um possível candidato a prefeitura pelo PMDB, José reitera seu pertencimento à família, respondendo: "é tradição familiar”.

Se estas discussóes, diria, internas à família revelam-se potencialmente conflituosas, não será diferente quando se coloca em questão o desempenho público de cada familiar durante o "tempo da política". É a partir deste aspecto que podemos voltar à reuniáo já citada e observar os significados implícitos aos temas levantados nas discussóes relatadas acima, adotando, agora, como foco a perspectiva que os envolvidos mantinham sobre a apreensão pública da família. Desta maneira, é possível observar como a discussão sobre a mudança de lado de uma figura política local - e o consequente debate acerca do papel dos traíras - detinha um sentido específico na reunião na casa de Alfredo. Havia um boato, já passado por um dos netos de Alfredo, de que uma de suas tias, Antônia, poderia estar mudando de lado. Conforme a versão deste sobrinho, seu tio, marido de Antônia, teria sido visto por "alguém" em uma reunião na casa de uma das lideranças da facção representada pelas siglas partidárias PSDB/PFL.

A mudança de lado de um parente próximo - ou seja, de alguém que poderia ser considerado publicamente como alguém da família - colocava em risco a identificação dos familiares de Alfredo à sua facção original. Fazia-se necessário retraçar as fronteiras familiares na politica, evitando o conflito entre as partes. Um dia, após esta primeira reunião, encontreime com Rita, que voltou a comentar sobre seu cunhado, que havia supostamente "virado". Rita contava-me que já havia falado antes com Antônia a respeito do assunto "que corria na família”, dizendo ter entendido o silêncio desta no almoço na casa de seu pai, em meio à conversa sobre a trairagem, como mais uma prova da veracidade dos boatos. Ainda conforme Rita, a posição da irmã justificava-se, já que "a esposa tem que acompanhar o marido", e que o silêncio dela deveria ser valorizado - já que, desta forma, "não trazia política para a família". Ainda assim, lembrava que "no fundo, eu sei que ela vai votar no PMDB. Imagina se ela não faz? A minha mãe iria se mexer no caixão!".

A possibilidade de apoiar publicamente uma facção e votar em outra reforça a necessidade de levar em conta a maneira como se dá a demonstração pública de seu posicionamento. Se, como já assinalei, são impensáveis atitudes 
I32 | Luciano Senna Peres Barbosa

como a de pedir votos para um estranho ou a alguém que não se reconhece o lado, ostentar propaganda de um candidato ou partido pode ser considerada uma afronta - assim como demarcar ostensivamente em espaço público seu apoio a uma determinada facção é visto como uma forma de desafio aos contrários. Esta situação pode trazer embaraço a familiares e até mesmo a parentes, porque eles se veem obrigados a responder as desavenças causadas por este membro aparentado. Sendo assim, espera-se que um familiar mantenha-se numa posição de relativa neutralidade, ou seja, só revele publicamente seu posicionamento em ocasióes socialmente definidas para tanto - a saber, os comícios e as carreatas.

Em todo caso, essa possibilidade de negociação da expressão de apoio torna-se cada vez mais limitada com o aumento da tensão ditada pela aproximação do dia do pleito. O alheamento em relação à disputa eleitoral torna-se difícil, especialmente quando, como no caso analisado, alguém que pode ser reconhecido como da família está envolvido numa trairagem. Por outro lado, a possibilidade de fazer da família uma protagonista da disputa política devido à associação pública (fora das ocasiōes nas quais a participação pública é autorizada) e reiterada a uma das facções traz consigo o risco de se ver alvo de humilhaçóes em caso de derrota, as quais são geralmente acompanhadas por efeitos práticos, como a perda de acesso aos benefícios mediados por políticos.

Não obstante este risco, o fato é que, mesmo sendo corrente a identificação de determinadas famílias ou indivíduos a um lado, especialmente durante o tempo da política, ser associado à facção derrotada nem sempre indica um cerceamento completo do acesso a benefícios mediados pela prefeitura ou por políticos. A exclusão desta rede de benefícios dá-se, em regra, quando a parte derrotada torna-se protagonista e, desta forma, símbolo da derrota sofrida a ser lembrada mesmo quando passado o "tempo da política". Daí a importância de qualificar seu posicionamento junto a um dos lados por uma associação legítima (prestar um favor a quem se tem uma dívida, por tradição familiar, ou simplesmente acompanhando a família), e não como a tentativa de suplantar o adversário ocasional.

É por esta razão que o aumento do acirramento da disputa faccional, dada à aproximação das eleiçóes, tende a aumentar o controle recíproco da maneira como familiares tornam pública a sua posição. É neste período que encontrei novamente Rita, demonstrando sua preocupação com seu sobrinho Carlos (filho de José, já citado anteriormente) devido aos boatos sobre seu envolvimento em uma briga entre partidários do PMDB e do PSDB em um clube da cidade.

A ação de Carlos refletir-se-ia na reunião familiar realizada na mesma semana. Tudo leva a crer que o seu envolvimento nos eventos relatados concedia maior visibilidade à família em meio à disputa eleitoral. Parece-nos que foi esta percepçáo que fez com que o tema da reunião naquela semana fosse a lembrança do episódio em que a família fora protagonista de uma das polêmicas públicas de uma eleição anterior.

Estavam presentes nesta reunião João, José e Cláudia, acompanhados de seus respectivos parceiros e filhos. Também participavam o irmão de Alfredo e sua esposa, que o visitam em vista de convidá-lo para sua festa de aniversário, dali a duas semanas (mais exatamente na véspera da eleição).

A ausência do marido de Antônia, a última a chegar à casa, foi rapidamente comentada, para logo em seguida trazerem-se à tona os eventos políticos. Os presentes debatiam os boatos sobre as brigas em tom jocoso, sem fazer qualquer comentário à participação do familiar. Em seguida, eles passaram a me relatar 
como a politica pode ficar "violenta", citando o episódio ocorrido nas eleições municipais de 2000 , ocasião na qual foram alvos de provocações recebidas logo em seguida à derrota nas eleições.

É Cláudia que toma frente do relato, contando diversas vezes com rápidos comentários dos outros familiares presentes. A história começa quando Cláudia, ainda com dez anos de idade, recebeu uma proposta de sua então vizinha, Isadora, para trabalhar como babá de sua filha recém-nascida. Obtendo a permissão de seu pai, Cláudia começa, então, a sua relação com sua "patroa" - que, segundo ela, tratavalhe como uma "filha". Prova disto seriam os convites recebidos por Cláudia para as festas da família de Isadora, como ela lembra: "eu sentei na mesa da família no casamento da irmã dela”.

Aos 17 anos, Cláudia, que também trabalhara como doméstica, é empregada por Iadora em sua loja, então recém-inaugurada. Na mesma época, seu irmão, José, fora trabalhar para o marido de Isadora em sua farmácia. Em 1996, o irmão de Isadora, um empresário estabelecido no Rio de Janeiro, decide lançar-se candidato pelo PSDB. De acordo com a versão de Cláudia, durante as semanas que antecederam as eleiçóes, pouco teria falado com sua patroa, embora tenha ficado "ressabiada" com a contratação de uma ajudante que tomara seu lugar como atendente, colocando-a, agora, como "faxineira" da loja. Apenas três dias antes das eleições, Isadora, então, dirige-se a Cláudia para pedir apoio ao seu irmão. Cláudia procura desvencilhar-se do pedido, justificando que não poderia confirmar seu apoio sem falar antes com seu pai sobre o assunto - uma maneira, segundo a entrevistada, de impedir que sua "patroa" lhe pedisse para fazer campanha na rua, já que não acreditava que ela fosse fazer tal pedido a seu pai. Conforme Cláudia, "por respeito", não participou das comemoraçóes da vitória do candidato do PMDB sobre o irmão de sua então "patroa". Contudo, no dia seguinte, ela recebe em casa, junto com José, uma carta de demissão. A reação de Cláudia é reveladora dos sentidos da afirmação pública e extensiva do posicionamento político: ela se dirige ao centro da cidade, vestindo uma camisa e portando uma bandeira da facção vitoriosa. Ainda no mesmo dia, ela receberia o advogado do partido que procurava convencê-la a abrir processo contra a Isadora por crime eleitoral. Cláudia não aceita, reafirmando sua superioridade moral, ao lembrar que sua ex-patroa "fora uma mãe" para ela por muito tempo.

A "vingança” de Cláudia viria com a reação de "partidários do PMDB" que, ao saberem do fato, teriam deixado de comprar na loja deIsadora e na farmácia de seu irmão, supostamente levando-os a um rápido declínio econômico e a posterior saída da cidade.

No entanto, a identificação da família com o partido devido a este evento em 1996 seria "paga" nas eleiçóes municipais seguintes, em que a vitória do PSDB foi seguida por uma carreata em direção à casa de Alfredo, que se tornou palco de diversas provocaçôes.

Seria difícil afirmar até que ponto a narrativa de Cláudia sobre os riscos do protagonismo político servia como uma advertência ao seu sobrinho. O fato é que este relato teria desdobramentos. Ao fim desta história, José pergunta: "e como, depois disso, vamos mudar de lado?" - em uma clara referência a atitude de seu cunhado, casado com Antônia. O silêncio que se segue após este comentário é a chave para o mal estar entre os presentes e a mudança do curso da conversa operada por Alfredo.

No dia seguinte, saberia num rápido encontro com Cláudia que, depois de minha saída e do irmão de Alfredo (portanto, os que não pertenciam à família), começara uma discussão entre José e Antônia, esta última acusando o ir- 
mão de "fazer feio", por "tentar brigar na frente dos outros por causa de politica", mas que, ainda conforme Cláudia, eles tinham se "ajeitado" depois - "coisa de família”, justificava.

Perguntado neste mesmo dia sobre como a mudança de lado poderia repercutir no restante da família, José aciona uma expressão usualmente empregada para sinalizar a desconsideração de parentesco: "Ele é cunhado, não é do meu sangue. É parente, mas não é da minha família”. José ainda enfatizaria, em seguida, o distanciamento em relação ao cunhado recorrendo à lembrança de eventos passados: cita ocasiōes em que este, "por ser rico", poderia ter ajudado mais a família, como, por exemplo, quando ele (José) ficou desempregado após a derrota do PMDB, em 2000.

Embora houvesse a tentativa de manter a briga como um elemento interno à família, a mesma dinâmica familiar já apontada - que parece fazer com que cada um busque num outro familiar o reconhecimento de sua versão em uma discussão - acaba tornando pública esta desavença. Evidência reforçada pela rápida passagem de Antônia e a ausência de seu marido na referida festa de aniversário do irmão de Alfredo, realizada na véspera do pleito.

Os últimos capítulos das reunióes familiares durante o tempo da política ocorreriam na semana seguinte à eleição. Nesta ocasião, os comentários concentravam-se nas comemorações da vitória do $\mathrm{PMDB}$, nas provocações aos candidatos batidos e aos seus cabos eleitorais e partidários. Também se iniciava neste período a avaliação do novo prefeito, especialmente no que se refere aos boatos sobre o planejamento das primeiras demissóes e indicaçóes da prefeitura. Criticava-se, por exemplo, a possível contratação de um rico para um cargo valioso - "imagina, ele vai receber quatro salários" - e a demissão de um partidário contrário que "sabia trabalhar”. É este último comentário que apon- ta para o gradual desaparecimento do recorte faccional e com este a retomada das relações familiares cotidianas, marcada na família de Alfredo pelo retorno das visitas do marido de Antônia à sua casa.

Sugerimos ao longo deste artigo que a vinculação familiar possui um papel central na definição da participaçáo no processo eleitoral no contexto analisado. Mais precisamente, as ligações familiares são empregadas pelos moradores como uma maneira de qualificar suas posiçôes durante o "tempo da política". Sendo assim, assinalei como, sob certas circunstâncias, o ato de justificar o posicionamento político baseando-se na vinculação familiar é capaz de manter a reputação do sujeito da fala, que, desta forma, nega uma relação de dependência com o candidato em que se propóe votar.

No entanto, o emprego desta justificativa implica em, ao menos, dois obstáculos que se interligam: o caráter circunstancial do estabelecimento das fronteiras familiares; e o fato de os compromissos políticos serem originários de lealdades pessoais que náo coincidem necessariamente com a vinculação familiar. Assim, sempre pode haver um suposto familiar posicionando-se publicamente a favor de outra facção ou candidato, como se pode acabar tendo de se posicionar a revelia da expectativa de lealdade familiar. Os moradores buscam superar estes obstáculos ao tentar impor publicamente sua definição das fronteiras familiares, levando ao que definimos como "reificaçáa" da família. Com efeito, se o "tempo da política" não é o único período de atualização das fronteiras familiares, este é, ainda assim, um dos principais períodos para tanto. 
Politics in Family. Kinship and political factions at a Zona da Mata's township in Minas Gerais.

abstract The aim of this paper is to analyze the ways in which family boundaries are updated during political disputes in a municipality in the region of Zona da Mata, Minas Gerais. More specifically, we intend to understand the meanings of following the vote of the family head, and how kinship relationships are used by individuals during the negotiations of political positioning in the electoral period. To this end, in the paper's first part, we present the ways in which the notions of familia and parente are manipulated in everyday life, revealing a specific way of defining the role of kinship relationships.

keywords Family. Politics. Elections. Political factions. Zona da Mata de Minas Gerais.

\section{Notas}

1. O nome do município e dos moradores citados é fictício, mantendo acordo firmado junto àqueles que colaboraram com sua paciência e simpatia pelo longo período desta pesquisa.

2. O presente trabalho inspira-se e procura manter diálogo com a série de pesquisas desenvolvidas pelo Nuap (Núcleo de Antropologia Política). A escolha do tema e a maneira como é abordado deve-se amplamente à minha leitura destas pesquisas e, especialmente, à influência dos trabalhos de Moacir Palmeira e Beatriz Heredia (2010).

3. Ao longo do artigo, os termos grifados em itálico indicam a referência à sua acepçáo local. A exceção refere-se aos termos família e parente, cujo grifo em itálico é usado para diferenciar um dos sentidos com que os moradores revestem estas palavras, tal como veremos mais adiante.

4. Reconheço o limite do termo "unidade doméstica" no que se refere à sua incapacidade de dar conta da flexibilidade e das mutaçôes desta unidade no tempo - como aponta Fonseca (2004). Tendo em vista esta observação, "unidade doméstica" é empregada aqui quando queremos nos referir à unidade constituída por pai, mãe, filhos solteiros e "agregados" (que podem ser tanto parentes quanto amigos).

5. Minha abordagem neste ponto, assim como em outros momentos do presente texto, deve-se à leitura do trabalho de John Comerford (2003), cuja pesquisa baseia-se em contexto semelhante. A análise das implicaçóes de se conceber o funcionamento da família, tomando como ponto de partida a flexibilidade da composição desta unidade, deve-se também à leitura do trabalho de Marques (2002).

6. Condição econômica aqui não deve ser entendida como um critério objetivo, mas como a maneira pela qual os moradores percebem a diferenciaçáo social.

7. A dissimulação desta mobilização nos casos que viemos até aqui denominando de "necessidades extraordinárias" desaparece nos casos em que sáo realizadas celebrações em comemoração à solução do problema.

8. A dissimulação e a fragmentação destas discussôes implicam numa limitação para o pesquisador que busca entender como estes são compostos. Desta forma, boa parte das informaçóes sobre o desenrolar destas negociaçóes familiares foi obtida a partir de comentários de terceiros.

9. A expressão "receber salário" é utilizada, geralmente, para se referir ao vínculo empregatício formal.

10. Emprego o conceito facção tal qual faz Palmeira: “(...) há múltiplas definiçôes de facções, mas entre os antropólogos há um certo consenso de que se trata de unidades de conflito, cujos membros são arregimentados por um líder com base em princípios variados. Em geral, estão em jogo conflitos considerados políticos (envolvendo o uso do poder público). As facções não são grupos corporados (via de regra os autores pensam-nas como quase-grupos, grupos diádicos não corporados, etc.)" (Palmeira, 1996, p. 54, nota 5).

11. O termo traíra - de onde se origina a variante trairagem - é usado para se referir àqueles que aderem à facção adversária.

12. Sobre este aspecto, ver Heredia (1996).

13. Geralmente, as candidaturas só passavam a ser de interesse do público com o início da propaganda eleitoral.

14. Foi Beatriz Heredia (1996) que chamou a atenção para como o "tempo da política" se articula aos esquemas de autoridade no interior da unidade doméstica. Ainda conforme Heredia (1996, p. 60), o período consagra-se à articulação da unidade doméstica ao espaço público, e é na relação com o espaço público que se evidencia a autoridade interna - no caso, do chefe de família. 


\section{Referências bibliográficas}

COMERFORD, John. Como uma familia: Sociabilidade, territórios de parentesco e sindicalismo rural. Rio de Janeiro: Relume Dumará: NUAP, 2003. 406p.

FONSECA, Cláudia. Família, fofoca e honra: etnografia de relações de gênero e violência em grupos populares. Porto Alegre: Editora da UFRGS, 2004. 248p.

HEREDIA, Beatriz M. A. de. Comunidade, Família, Política In: PALMEIRA, M.; GOLDMAN, M. (Org.). Antropologia, Voto e Representação Política. Rio de Janeiro: Contracapa, 1996. 235p.

MARQUES, Ana Cláudia. Intrigas e questôes: Vingança de família e tramas sociais no sertão de Pernambuco. Rio de Janeiro: Relume Dumará: NUAP, 2002. 352p.
PALMEIRA, Moacir. Política, Facções e Voto. In: PALMEIRA, M.; GOLDMAN, M. (Org.). Antropologia, Voto e Representação Política. Rio de Janeiro: Contracapa, 1996.

PALMEIRA, Moacir; HEREDIA, Beatriz M. A. de. Política ambígua. Rio de Janeiro: Relume Dumará: NUAP, 2010. 189p.

VILLELA, J. M. e MARQUES, A. C. Sobre a Circulação de Recursos nas Eleiçôes Municipais no Sertão de Pernambuco. In: HEREDIA, Beatriz M. A. de; TEIXEIRA, Carla; BARREIRA, Irlys (Orgs.). Como se fazem Eleiçôes no Brasil. Rio de Janeiro: Relume Dumará, 2002. 274p.

\section{autor Luciano Senna Peres Barbosa}

Doutor em Antropologia / IFCS - UFRJ

Recebido em 30/03/2012

Aceito para publicação em 01/10/2012 